Derleme/Rewiev

\title{
Nörolojik hücrelerde TRPM2 katyon kanallarının moleküler mekanizmalardaki rolleri
}

\section{Role of TRPM2 cation channels on molecular pathways in neurological cells}

\author{
Cemil Özgül, Mustafa Nazıroğlu*
}

Süleyman Demirel Üniversitesi, Tip Fakültesi, Biyofizik Anabilim Dall, Isparta

\begin{tabular}{|c|c|}
\hline MAKALE BİLGILERİ & ÖZET \\
\hline Makale G & \multirow{13}{*}{$\begin{array}{l}\text { Vücuttaki tüm organlar özellikle merkezi sinir sistemi, serbest radikal hasarına karşı du- } \\
\text { yarlıdır. Beynin yüksek oksijen tüketimi, kolayca okside olabilen zengin yağ asitlerini ba- } \\
\text { rındırması, diğer organlara göre düşük seviyede antioksidan enzim ve antioksidan içermesi } \\
\text { onu serbest oksijen radikalleri tarafından birincil hedef haline getirmektedir. } \mathrm{Na}^{+} \text {ve } \mathrm{Ca}^{+2} \\
\text { iyonlarına geçirgen melastatine bağlı "transient receptor potential } 2 \text { (TRPM2)" katyon ka- } \\
\text { nalları ya } \mathrm{Ca}^{+2} \text { ile uyum içinde olan ADP-riboz tarafından ya da oksidatif stres }\left(\mathrm{H}_{2} \mathrm{O}_{2}\right) \\
\text { tarafından kanalların enzimatik Nudix bölgesine bağladığı ve ADP-riboz pirofosfataz'ın } \\
\text { aktive olduğu rapor edilmiştir. Bu enzim aktivasyonu sonucunda da TRPM2 kanallarının } \\
\text { açıldığı gözlemlenmiştir. Bu derleme çalışmasında, nöronal hücrelerde, TRPM2 inhibis- } \\
\text { yonuna yol açtığı düşünülen ADPR ve } \mathrm{H}_{2} \mathrm{O}_{2} \text { maddeleri tam anlaşılmadığı için nörolojik } \\
\text { hastalıklardaki bipolar hastalıklar kadar mikroglia, hipokampus ve beyindeki ADPR ve } \\
\text { oksidatif stresin TRPM2 kanalları üzerindeki etkileri gözden geçirilmiştir. Mikroglia ve } \\
\text { hipokampal hücrelerde TRPM2 katyon kanallarının hem ADPR hem de } \mathrm{H}_{2} \mathrm{O}_{2} \text { tarafindan } \\
\text { açıldığı gözlemlendi. Buna ek olarak, nörolojik hastalıklarda } \mathrm{H}_{2} \mathrm{O}_{2} \text { nin TRPM2 aktivasyo- } \\
\text { nundan sorumlu olduğu gözüküyor. Bipolar hastalıkların etiyolojisinde genetik faktörler } \\
\text { önemli rollere sahip olabilirler. }\end{array}$} \\
\hline $06 / 07 / 2010$ & \\
\hline Kabul & \\
\hline *Yazıșma Adresi & \\
\hline Mustafa Nazıroğlu & \\
\hline Süleyman Demirel Üniversitesi Tıp & \\
\hline Fakültesi Biyofizik A.D. Morfoloji Binasi, & \\
\hline Çünür, Isparta & \\
\hline e-posta: mnaziroglu@med.sdu.edu.tr & \\
\hline Anahtar Kelimeler: & \\
\hline TRPM2 & \\
\hline $\mathrm{Ca}^{+2}$ & \\
\hline Nörolojik Hücreler & \\
\hline
\end{tabular}

Oksidatif Stres

ADPR

Glial Hücreler

Key Words :

TRPM2

$\mathrm{Ca}^{2+}$

Neurological Cells

Oxidative Stress

ADP - ribose

Glial cells.

\begin{abstract}
Of all the organs in the body, the central nervous system is especially sensitive to free radical damage. Its high consumption oxygen, rich content of easily oxidizible fatty acids, relatively low content of antioxidant enzymes and antioxidants, a make it a prime substrate for damage by ROS. The $\mathrm{Na}^{+}$and $\mathrm{Ca}^{2+}$-permeable melastatin related transient receptor potential 2 (TRPM2) cation channels can be gated either by ADP-ribose (ADPR) in concert with $\mathrm{Ca}^{2+}$ or by hydrogen peroxide $\left(\mathrm{H}_{2} \mathrm{O}_{2}\right)$, an experimental model for oxidative stress, binding to the channel's enzymatic Nudix domain. Since the mechanisms that lead to TRPM2 inhibiting in response to ADPR and $\mathrm{H}_{2} \mathrm{O}_{2}$ are not understood in neuronal cells, we reviewed the effects of ADPR and oxidative stress in neurological cells such as microglia, hippocampus and brain as well as neurological diseases such as bipolar diseases. It was observed that TRPM2 cation channels in microglia and hippocampal cells were gated both by ADPR and $\mathrm{H}_{2} \mathrm{O}_{2}$. In addition, $\mathrm{H}_{2} \mathrm{O}_{2}$ seems to responsible activation of TRPM2 in neurological diseases. Genetic defects may be have important role in etiology of bipolar diseases.

J. Exp. Clin. Med., 2010; 27:144-151
\end{abstract}

(C) 2010 OMÜ Tüm Hakları Saklıdır.

\section{Giriş}

Vücuttaki tüm organlar özellikle beyin oksidatif strese maruz kalabilirler ve çoklu doymamış yağ asitlerinin otooksidasyonu (self-oksidasyon) yolu ile devamlı olarak üretilen reaktif oksijen türlerine (ROS) maruz kalabilirler. Merkezi Sinir Sistemi serbest radikal hasarına oldukça hassastır. Beynin yüksek oksijen tüketimi, kolayca okside olabilen zengin yağ asitlerini barındırması, diğer organlara göre düşük seviyede antioksidan enzim ve antioksidan vitamin içermesi onu ROS tarafından birincil hedef haline getirmektedir.

Beyin, diğer organlarla karşılaştırıldığında vücuda alınan oksijenin büyük bir kısmını (\% 20) kullanır. Bu yüksek oksijen kullanımı ve metabolizmasının hızlı oluşu 
beyinde serbest radikal üretim miktarını arttırabilir (Butterfield, 2003). Beyin proteinlerden ve bol miktarda fosfolipitlerden oluşan zarlardan oluşmuştur. Bu fosfolipitler de araşidonik asit ve docohexaenoic asitler gibi okside çoklu doymamış yağ asitlerinden oluşur (Halliwell, 2006). $\mathrm{Bu}$ doymamış yağ asitleri serbest oksijen radikaline karş1 savunmasız bir durumdadırlar. Çünkü zayıf çift bağlarla birbirine tutunan hidrojen iyonlarını içermektedir. ROS da hasar vermek için bu zayıf bağlı hidrojen iyonlarını bir hedef olarak görmektedir (Özmen ve arkadaşları, 2007). Beyin fosfolipitlerinin değişikliklerine neden olabilen oksidatif hasar nörolojik hastalıklarda rol oynuyor olabileceği ileri sürülmüş̧ür (Nazıroğlu, 2007 a ve b).

Beyin ve nörolojik hücreler peroksidatif hasara karşı antioksidanlarca korunmaktadırlar (Halliwell, 2006; Nazıroğlu, 2007b). Glutatyon peroksidaz (GSH-Px) hidrojen peroksiti $\left(\mathrm{H}_{2} \mathrm{O}_{2}\right)$ indirgeyerek suya katalizler. GSH-Px de organik hidrojen peroksidi ortamdan uzaklaştırabilirler. Glutatyon (GSH) hücresel fonksiyonların geniş bir alanında bir hidroksil radikali $(\mathrm{OH})$, bir singlet oksijen $\left(\mathrm{O}_{2}{ }^{1}\right)$ tutucusudur (Rayman, 2009). Vitamin-E ( $\alpha$-tocopherol) hücrenin lipit fazındaki en önemli antioksidanıdır. Vitamin E vücudun metabolik ürünler vasıtasılyla hücreye hasar veren serbest radikallerin etkilerine karşı hücreleri korumada rol oynar (Halliwell, 2006; Nazıroğlu, 2007 b). Vitamin $\mathrm{C}$ (askorbik asit) serbest radikal tutucusu olmasının yanı sira E vitamininin aktif formuna doğru dönüşebilmektedir (Nazıroğlu, 2010). Beyin askorbik asit konsantrasyonu vücut dokuları içinde karaciğer ve böbrekte olduğu gibi beyinde de çok düşüktür (Nazıroğlu, 2010). Vitamin A (retinol) retinoitler için bir prohormon olarak hizmet vermekte iken sitoplazma ve zar alanlarında da sinyal iletimi ile ilgilenmektedir (Tafti ve Ghyselinck, 2007).

Bir fonksiyonel enzimi ölçü alarak; C-terminal alan içerisinde, TRPM2, TRPM6, TRPM7 bilinen ka-

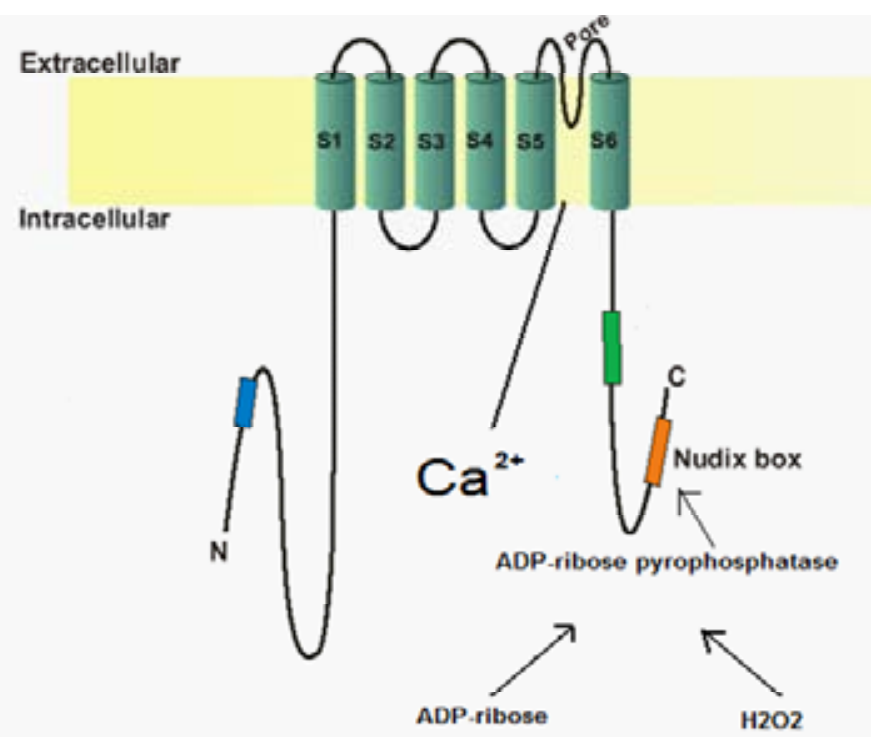

Şek. 1: TRPM2 katyon kanallarının moleküler yapısı. Oksidatif stres ve/veya ADP-Ribozla aktive edilen ADP-Riboz fosfataz enzimi TRPM2 kanalının açılmasına neden olur (Nazıroğlu, 2007). nallar arasında benzersiz özelliklere sahiptirler. TRPM2 iyon kanallarının $\mathrm{N}$ ucu, bilinen diğer Nudix Hidrolaz (NUDT9-H) enzimleri kadar etkin olmamasına rağmen, Adenozin di-fosfat (ADP) ve Adenozin di-fosfat Ribozu (ADPR) bağlayabilen bir Nudix Hidrolaz türüdür (Kühn ve ark., 2005) (Şek. 1).

TRPM2'nin NUDT9-H'a ADPR bağlaması kanalı etkinleştirir ve elektrokimyasal gradyenti de katyonların geçişine izin verir. TRPM2 plazma zar kanalı olduğu için, TRPM2 açıldığında $\mathrm{Ca}^{+2}$ ve $\mathrm{Na}+$ iyonları hücre içine akacaktır.

ADPR TRPM2'nin en güçlü aktivatörü olmasının yanı sıra daha az güçlü aktivatörleri de mevcuttur (Hara ve ark., 2002; Heiner ve ark., 2006). $\mathrm{H}_{2} \mathrm{O}_{2}$ gibi oksidanlar nikotinamid adanin dinükleotid $\left(\mathrm{NAD}^{+}\right)$ve cyclic $\mathrm{ADPR}$ (cADPR) içerir. $\mathrm{NAD}^{+}$ve $\mathrm{H}_{2} \mathrm{O}_{2}$ ADPR'nin hücre içi düzeyini arttırır. Ve böylece TRPM2 kanalları direkt ya da dolaylı olarak açılabilir (Hara ve ark., 2002; Perraud ve ark., 2005; Nazıroğlu ve Lückhoff, 2008a).

\section{TRP Üst Ailesi}

"Transient Reseptor Potential (TRP)" katyon kanalları üst ailesi voltaja duyarlı $\mathrm{Ca}^{+2}$ 'a geçirgen katyon kanallarının geniş bir yelpazesiyle uzlaştırılmaktadır. 28 memeliye ait TRP kanalları yedi alt familyaya grupland1rilmıştır. Bunlar;

TRP conancial (TRPC) yedi alt aileden, TRP vanilloid (TRPV) alt1 alt aileden, TRP melastatin (TRPM) sekiz alt aileden, TRP polycystein (TRPP) üç alt aileden, TRP mucolipin (TRPML) üç alt aileden ve TRP ankyrin (TRPA) bir alt aileden oluşmaktadır. Tüm bu TRP katyon kanalları henüz tam olarak karakterize edilememesine rağmen, birçok insan hastalığ 1 onların katılımıyla ortaya çıktığından bunlara olan ilgi gün geçtikçe artmaktadır. Kanal gözeneğinin 5. ve 6 . segmentleri arasında bulunan bir iletken iyon etrafinda homo veya heterotetromerik düzenlemelerle TRP kanalları voltaj-kapılı $\mathrm{K}^{+}$kanallarına benzer olarak basit bir yapıya sahiptir (Clapham, 2003). Dördüncü transmembran segmenti ise pozitif yüklü değildir. TRPV N ucu ve TRPV tekrarlı bağlayıcı, çoklu ankyrin içerir. TRPC ve TRPM kanallarına ait 6 . segmentin $C$ terminal kısmı “TRP alanı” içerir. TRPM2 kanalarında iyon akış1 5. ve 6. segmentler arasında gerçekleşmektedir. Ayrıca, TRPM2 ve TRPC kanallarının N ucu ADPR pirofosfataz (ADPR'yi, riboz 5- fosfat ve adenozin monosfosfata parçalar ve kanal açılır) enzim aktivasyonu içermektedir. ADPR pirofosfataz aktivasyonu TRPV kanallarında yoktur. Buna ilaveten bütün TRP kanalları çok yönlü düzenleyici protein etkileşim alanlarına sahiptir. Çok yönlü Protein Kinaz A (PKA) ve Protein Kinaz C (PKC) varsayılan fosforilasyon alan fonksiyonları tanımlanmış ve kısmen test edilmiştir. Bir de birkaç TRP kanallarında Phosphatidylinositide 3-kinase 
SH2- tanıma alanları varlığ ispatlanmıştır (Watanabe ve ark., 2008).

TRP kanalları ya direkt olarak plazma zarlarındaki $\mathrm{Ca}^{+2}$ giriş kanalları gibi davranmakta ya da $\mathrm{Ca}^{+2}$ giriş kanallarının modülasyonu için itici güç olan zar potansiyelini değiştiren sitozolik serbest $\mathrm{Ca}^{+2}$ kanallarında değişime yardımcı olmaktadırlar. Karakterize edilmiş tüm işlevsel TRP kanalları (TRPM4 ve TRPM5 kanalları dıșında) $\mathrm{Ca}^{+2}$ için geçirgendirler. Bu durum sadece monovolent katyonlar için geçerli değil, aynı zamanda $\mathrm{Ca}^{+2}$ ve $\mathrm{Mg}^{+2}$ içinde geçerli olacaktır. İki memeli TRPleri, TRPV5 ve TRPV6, $\mathrm{Ca}^{+2}$ 'a çok geçirgendir. TRPM6 ve TRPM7 $\mathrm{Mg}^{+2}$ 'a çok geçirgen, TRPV1,TRPML1 ve TRPP3 kanalları da $\mathrm{H}+$ iyonlarına çok geçirgendir (Nillius, 2007).

\section{TRPM}

TRPM alt ailesinin sekiz üyesi vardir ve bunlar 4 grup içersinde yer alırlar. Bunlar; TRPM2/TRPM8, TRPM1/TRPM3, TRPM4/TRPM5 ve TRPM6/TRPM7 dir (Nazıroğlu, 2007b) (Şek. 2).

Hem TRPM6 hem de TRPM7 fonksiyonel $\mathrm{COOH}$

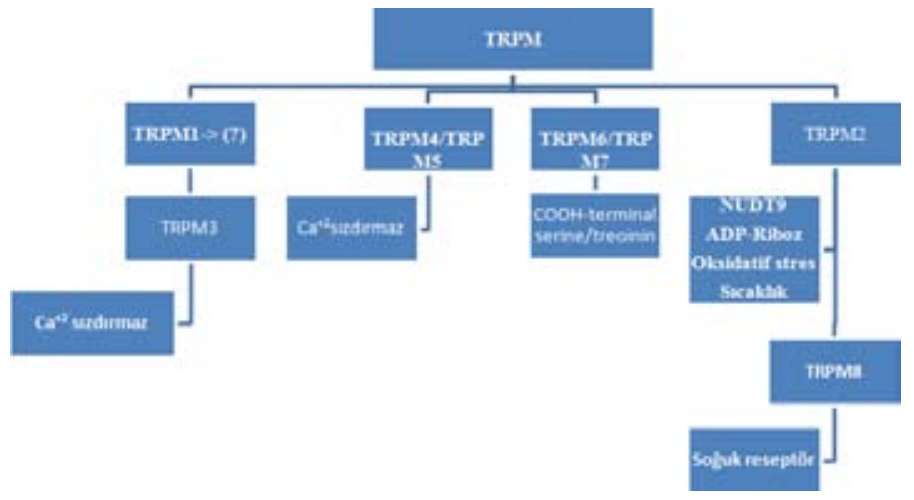

Şek. 2: TRPM kanalları sekiz alt üyeden oluşur ve bunlar dört ana grupta toplanır

terminal serine/treonin kinaz içerirken, TRPM2 ADPR pirofosfataz faaliyeti gösteren fonksiyonel NUDT9 homoloji alanı içerir. $\mathrm{Ca}^{+2}$ ' u çok geçirenden (TRPM6/TRPM7 ve TRPM3 'ün ek yerine kadar) $\mathrm{Ca}^{+2}$ 'u geçirmeyene kadar (TRPM4 veTRPM5) $\mathrm{Ca}^{+2}$ geçirgenliği farklılıklar gösterir. Buna rağmen TRPM1 kanalı hariç tüm TRPM katyon kanalları bu güne kadar karakterize edilmemişlerdir. TRPM4 ve TRPM5 1sıya duyarlı $\mathrm{Ca}^{+2}$ aktif kanallarıdır (Nillius ve arkadaşları, 2007). TRPM2 ADPR, $\mathrm{H}_{2} \mathrm{O}_{2}$ ve sicaklıkla aktif hale gelir. TRPM3 kanalları TRPM6 ve TRPM7 kanallarına benzer şekilde hücre içi $\mathrm{Mg}^{+2}$ seviyesi vasıtasıyla düzenlenir. Hücre şişmesi ve sphingosine olaylarının meydana gelmesi önemli aktivasyon yoluyla TRPM3 aktivasyonunun rapor edildiğini gösterir. TRPM8 ise pek bilinmeyen soğuk reseptördür (Hara ve ark., 2002; Clapham, 2007; Nillius ve ark., 2007; Nazıroğlu ve ark., 2007; Yamamoto ve ark., 2008).

\section{TRPM2 Kanalları}

TRP kanallarından biri TRP melastatin (TRPM) olarak adlandırılmıştır. Çünkü kurucu üyesi olan TRPM1, ilk metastatik melanomlar (kanserli dokularda) ile bağlantılı olarak tanımlanmıştır (Clapham, 2007). Önceleri TRPC2 ve LTRPC2 olarak bilinen TRPM2 kanallar1 ilk olarak 1998 y1lında tespit edildi. Daha sonra da TRPM ailesinin bir üyesi olarak kabul edildi (Clapham, 2003). Tüm bu sekiz adet TRPM aile üyeleri ya fare modellerindeki fonksiyonel çalıșmalar ya da genetik kanıtlar tarafindan hastalıklarla bağlantılı olduğu anlaşıldı (Nillius ve ark., 2007).

\section{Mekanizmalar \\ 5. TRPM2 Aktivasyonu Üzerindeki Moleküler}

Aktif TRPM2 katyon kanallarının açılması üzerinde üç hücre dişı etken (aktivatör) bilinmektedir. Bunlar; Oksidatif stres, $\mathrm{ADPR} / \mathrm{NAD}^{+}$metabolizması ve tümör nekroz faktörü alfa dır (Hara ve ark., 2002). TRPM2 için vücut 1sısı endojen bir ko-faktör gibi davranması sebebi ile TRPM2 kanallarının sicaklığa duyarlı olabileceği tahmin edilmektedir (Togashi ve ark., 2006).

\section{Oksidatif Stres}

Süperoksit, $\mathrm{H}_{2} \mathrm{O}_{2}$ ve singlet oksijen içeren ROS aşırı üretildiğinde veya enzimatik ve non-enzimatik savunma işlemleri engellendiğinde, mitojenik sinyal iletimi gibi karmaşık süreçlerde hücre habercisi olarak hücrenin düzenlenmesinde rol alırlar (Nazıroğlu, 2007 a ve b). Birçok hücre içi ve dışı molekülleri nöronal doku hasarına ve apoptozuna katılabilirken, oksidatif stres birikimi, ROS'un aşırı üretimi nedeniyle hücre hasarı ve ölümü için potansiyel bir faktör olarak görünmektedir.

Oksidatif stres, $\mathrm{H}_{2} \mathrm{O}_{2}$ uygulamas1 bir deneysel oksidatif stres modeli olarak, TRPM2 kanallarını uyarmak için kullanılmaktadır. TRPM2 kanal aktivasyonlarına bağ1 serbest hücre içi $\mathrm{Ca}^{+2}$ artışı pankreas $\beta$ hücrelerinde (Inamura ve ark., 2003), insan nötrofil granülosit hücrelerinde (Heiner ve ark., 2003) ve hem de U937 monosit hücre serisinde (Perraud ve ark., 2001; Yamamoto ve ark., 2008) gözlenmiştir. $\mathrm{H}_{2} \mathrm{O}_{2}$ kaynaklı TRPM2 kanal aktivasyonu için kesin aracı moleküllerin tespit edilmiştir. Ancak, $\mathrm{H}_{2} \mathrm{O}_{2}$ kaynaklı TRPM2 kanal aktivasyonu için kesin aracı moleküllerin tespit edilmesidir. TRPM2'nin ROS duyarlılı̆̆ $\mathrm{NAD}^{+}$veya mitokondri ve protein oksidasyonu üzerinden salınan ADPR tarafindan aracılık edilmektedir (Hara ve ark., 2002; Wehage ve ark., 2002; Guse ve ark., 2005). $\mathrm{H}_{2} \mathrm{O}_{2}$ ve cADPR düşük konsantrasyonları ADPR 'un etkisini potansiyalize etmek için ve daha yüksek konsantrasyonlarda doğrudan TRPM2 kanalını açmak için etkileri oldukları ileri sürülmüştür (Massullo ve ark., 2006)

TRPM2 Aktivasyonu Üzerindeki Oksidatif Stres ve ADP-riboz/NAD Ürünlerinin Rolleri

TRPM2 üzerinden $\mathrm{Ca}^{+2}$ girişi ADPR üretiminin gerçekleşmesiyle meydana gelir. ADPR bir mitokondriyal kaynaktan veya poly-ADPR'un alternatif aktivasyonu üzerinden ortaya çıkabilir (Guse ve ark., 2005).

$\mathrm{NAD}^{+}$'ın TRPM2 kanalını uyardığı bildirilmiștir (Hara ve ark., 2002). TRPM2, kendisinin C terminal sito- 
Tablo 1. Farklı nöronal hücrelerde TRPM kanallarının aktivasyonu ve inhibisyonu

\begin{tabular}{|l|l|l|l|}
\hline Aktivatörler & Hücreler & Etkileri & Referans \\
\hline $\begin{array}{l}\text { Hem ADPR hem } \\
\text { oksidatif stres }\end{array}$ & Glia & Aktivatör & Kraft ve ark. [2004] \\
\hline oksidatif stres & Striatal nöronlar & Aktivatör & $\begin{array}{l}\text { Smith ve ark. [2003] } \\
\text { Hill ve ark. [2006] }\end{array}$ \\
\hline $\begin{array}{l}\text { Hem ADPR hem } \\
\text { oksidatif stres }\end{array}$ & Kortikal nöronlar & Aktivatör & $\begin{array}{l}\text { Kaneko ve ark. } \\
{[2006]}\end{array}$ \\
\hline ADPR & $\begin{array}{l}\text { Piramidal nöronlar } \\
\text { ve hipokampüsün } \\
\text { CA1 internöronlar1 }\end{array}$ & Yetersiz & Etkisi yok ve ark. [2004] \\
\hline Kksidatif stres & $\begin{array}{l}\text { Piramidal nöronlar } \\
\text { ve hipokampüsün } \\
\text { CA1 internöronları }\end{array}$ & Aktivatör & Olah et al., [2009] \\
Astroglia ark. [2009] & Aktivatör & $\begin{array}{l}\text { Bond ve Greenfield } \\
\text { [2007] }\end{array}$ \\
\hline
\end{tabular}

zolik kuyruğunda ki bir Nudix Alanı olarak bilinen karakteristik yapısal bir özelliğe sahiptir (Perraud ve ark., 2001). Nudix alanı indirgenmiş nükleozid difosfotazın bir sınıfında olduğu bilinen pirofosfotazların bir uzlaşma bölgesidir (Nazıroğlu, 2007b) (Şek. 1). Aslında, $\mathrm{NAD}^{+}$ürününü ve cyclic ADPR'nin sentezleyen, kalsiyum serbest ryanodin reseptörleri aracılığı ile uyarılan hücre içi ikincil haberciyi temsil eden ADPR TRPM2 nudix alanına yapıșır (Nazıroğlu, 2009). TRPM2 tarafindan ADPR hidrolize edilirken, aynı zamanda o da TRPM2 yi etkinleştirir. Ve ADPR infüzyonu sırasında patch pipeti yardımıyla TRPM2 akımları indüklenir (Perraud ve ark., 2001; Hara ve ark., 2002). $\mathrm{NAD}^{+}$in da TRPM2 kanalını uyardığı bildirilmiştir (Hara ve ark., 2002; Kühn ve Lückhoff, 2004; Kühn ve ark., 2005). Yukarıda bahsedilen $\mathrm{NAD}^{+}$in TRPM2 kanalını doğrudan etkilediğini son çalışmalarımızda gözlemledik. Dolayısıyla, bizim sonuçlarımız NAD ${ }^{+}$in TRPM2 kanalını uyardığı fikrini desteklemektedir (Nazıroğlu ve Lückhoff, 2008 a ve b).

Daha önce yayınlanmış verilere göre, $\mathrm{H}_{2} \mathrm{O}_{2}$ tarafından TRPM2 kanallarının açılabileceği ve bağımsız ADPR kanalını açmak için $\mathrm{H}_{2} \mathrm{O}_{2}$ 'nin uygun olduğu öne sürülmüştür (Hara ve ark., 2003; Wehage ve ark., 2002). Çünkü mitokondri içinde büyük ölçüde TRPM2 aktivasyonu $\mathrm{H}_{2} \mathrm{O}_{2}$ aracilığıyla ADPR konsantrasyonunun artırıldığ $1, \mathrm{H}_{2} \mathrm{O}_{2}$ kanal açma mekanizması mitokondride ADPR' i sentezlemek için onun yeteneğine dayandığ 1 kanıtlanmıştır. Fakat, (Kolisek ve ark., 2005) son zamanlarda yapilan çalışmalar gösterdi ki; $\mathrm{H}_{2} \mathrm{O}_{2}$ mitokondride ve aynı zaman-

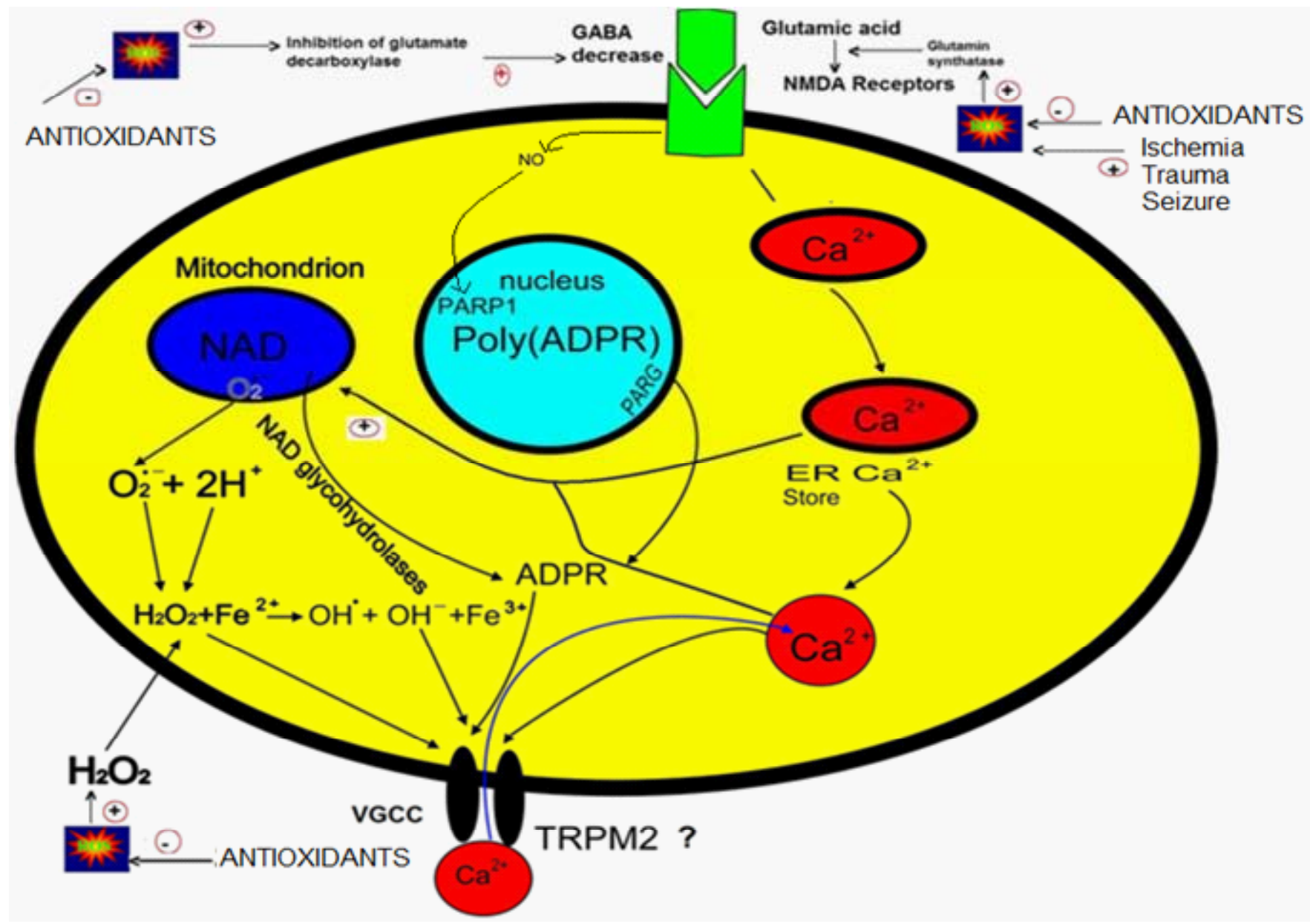

Şek. 3: ADPR ve TRPM2 kanal aktivasyonu ile oksidatif stres arasındaki ilişkinin şematik sunumu. ADPR üretimi G proteine bağlı reseptörlere ligand kanal aktivasyonu ile bașlatılır. Reseptör aktivasyonu aynı zamanda intrasellüler $\mathrm{Ca}^{+2}$ yoğunluğunun yükselmesi "inositol trifosfat (IP3)" tarafından hücre içi organellerden $\mathrm{Ca}^{+2}$ serbest bırakılmasını sağlar. TRPM2 hücreye doğru güçlenen TRPM2 aktivasyonuyla bir pozitif geri bildirim ile Ca ${ }^{+2}$ girişi sağlar. Alternatif kaynaklar ADPR içeren mitokondri ve çekirdektir. ADPR polimerlerinin stimülasyon sonrası poli (ADPR) polimeraz-1 (PARP-1)'e ve sonrasında poly (ADPR) glikohidrolaz (PARG) tarafından ADPR'ye hidroliz edilir. Bu olay hücreyi apoptozise gidinceye kadar uyarabilir. Sitozolde Ca ${ }^{+2}$ artışı mitokondride depolarizasyon ve porların açılması veya hücre dışından sitozole $\mathrm{H}_{2} \mathrm{O}_{2}$ lerin gelişi daha fazla nitrik oksit sentaz (NOS) ve ROS üretilir. ADPR ve ROS geri bildirim mekanizması ile TRPM2 kanallarının açılması yolu ile sitozole $\mathrm{Ca}^{+2}$ akışını artırır (Naziroglu, 2007). 
da ADPR' nin potansiyalize ko-faktörünün bir fonksiyonu olarak ADPR' nin serbest bırakılmasını başlatırken, $\mathrm{H}_{2} \mathrm{O}_{2}$ TRPM2 kanalını harekete geçirmek için kendi kendine yeterli uyarıcılar oluşturabilmektedir. Yine son zamanlarda yaptığımız çalışmalarımıza göre, Whole Cell (tüm hücre) yöntemiyle alınan kayıtlarda TRPM2 aktivasyonu $\mathrm{H}_{2} \mathrm{O}_{2}$ tarafından göreli hızlı olduğundan ve alınmış zar yamalarındaki karışım tek kanallı faaliyetleri tetiklediğinden $\mathrm{H}_{2} \mathrm{O}_{2}$ aracılı TRPM2 aktivasyonu doğrudan bir kanal açma mekanizması olarak görünmektedir (Nazıroğlu ve Lückhoff, 2008a) (Şek. 3). Hücrelerin bulunduğu patch çemberine $\mathrm{H}_{2} \mathrm{O}_{2}$ eklendikten sonra hücre insite-out (içi dışarıda) kayıtları alınıp, hücre içi tampon ile yıkandı ve daha sonra $\mathrm{H}_{2} \mathrm{O}_{2}$ tekrar verildi. Kanalın hücre içi bileşeni olmamas1na rağmen $\mathrm{H}_{2} \mathrm{O}_{2}$ 'nin ikinci bir yönetimiyle kanal tekrar etkinleştirildi. $\mathrm{Bu}$ deneyimden yola çıkarak alınmış zar yamasında gözlenen tek kanal aktivitesi büyük olasılıkla doğrudan kanal açma mekanizma kaynaklı olduğu sonucu çıkmaktadır.

TRPM2 aktivasyonu üzerinde metodolojik problemler $\mathrm{NAD}^{+}$, ADPR ve $\mathrm{H}_{2} \mathrm{O}_{2}$ sebebiyle farklı raporların verilmesine neden olmuştur. Örneğin; "human embryonic kidney 293 (HEK293)" hücrelerinde bir çalışmada, $\mathrm{H}_{2} \mathrm{O}_{2}$ tarafindan aktive edildiği rapor edildi (Wehage ve ark., 2002). Daha sonraki deneylerde, yeterli bir tutarlilık ile TRPM2 vahşi bir tipinin kullanıldığ "Chinese hamster ovary (CHO)" hücre ifade sisteminde $\mathrm{H}_{2} \mathrm{O}_{2}$ ile uyarım çoğu araştırmacılarca mümkün olmasına rağmen $\mathrm{NAD}^{+}$ ile uyarabilen çalışmalarda mevcuttur (Kolisek ve ark., 2005).

$\mathrm{H}_{2} \mathrm{O}_{2}$, ADPR ve metabolitleri ile TRPM kanallarının aktivasyonu çalışılmasında farklı hücre tiplerinin kullanılması ikinci bir farklı sorunu ortaya çıkarmaktadır. Öte yandan TRPM2'nin endojen ifadesiyle birlikte hücrede hücre-özel işlemini sunmak için $\mathrm{H}_{2} \mathrm{O}_{2}$ tarafindan kanal aktivasyonu görünür. Örneğin, HEK293 hücrelerinde (Hara ve ark., 2002; Wehage ve ark., 2002), CHO hücrelerinde (Nazıroğlu ve ark., 2007), GRI-GI rat insülinoma hücrelerinde (Fonfria ve ark., 2005), TRPM2 kanal1 $\mathrm{H}_{2} \mathrm{O}_{2}$ tarafından aktive edilebilmektedir. Fakat insan nötrofil granülosit hücrelerinde $\mathrm{H}_{2} \mathrm{O}_{2}$ TRPM2 kanalını aktive edememektedir (Heiner ve ark., 2003). Kolisek ve ark. (2005) HEK293 hücrelerini kullandılar ve cADPR tarafından aç1lan TRPM2 kanalı bileşik tarafından uyarıldığını gözlemlediler. Sonra, bu rapor sonuçları Gasser ve ark. (2006) tarafindan desteklenmiş ve Jurkat hücrelerinde TRPM2 kanalları cADPR tarafından açılmıştır. Fakat, daha yeni bir çalışma nötrofil granülositlerinin sonuçlarını desteklemedi (Heiner ve ark., 2006) ve cADPR'nin uyarımıla TRPM2 kanallarının açılmadığını rapor edildi.

\section{lışmaları}

Genetik Defektli Fareler Üzerinde TRPM2 Ça-

TRPM2 kanalının biyolojik rolünde önemli bir ilerleme TRPM2-KO genetik defektli fareler üzerinde yapılan bir yeni çalışma tarafından sağlanmıştır (Yamamoto ve ark., 2008). Monositlerden TRPM2-KO farelerinden inflamatuar protein-2 sitokin bozulmasinda ve makrofaj üretiminde $\mathrm{H}_{2} \mathrm{O}_{2}$ kademeli sinyal aktivitesi yer alır.

\section{Rolleri}

\section{Nörolojik Hücrelerde TRPM2 Kanallarının}

Northern Blotting ve kontatif PCR teknikleri Merkezi Sinir Sistemin (MSS)'nin çoğunluğunda TRPM2 kanallarının varlığını göstermiştir. Ancak glia içinde kendisinden ayırt edilmek için nöronlarda bu ifadeye izin verilmediği için homojen doku örneklerinden bu kanıt elde edilmiştir. Serebellar granül ve astrositlerde TRPM2 transkripti veya fonksiyonel kanallarını tanımak için yapılan yeni bir çalışma tarafından böyle bir ayrım yapmanın önemi vurgulanır (Kraft ve ark., 2004). Nöronal olmayan hücrelerde TRPM2'nin MSS dağılımı kendi ifadesiyle haberleşen ve öneri götürülen mikroglia hücrelerinde TRPM2 tespit edildi (Perraud ve ark., 2003; Kraft ve Harteneck, 2005; Olah ve ark., 2009).

\section{Mikroglia ve Astroglia Hücrelerinde TRPM2 Kanallarının ve Oksidatif Stresin Rolleri}

Mikroglia gibi fagositik hücrelerde NADPHoksidaz oksijeni indirgeyerek süperoksit radikalini oluşturan bir elektron taşıma sistemidir. Fizyolojik koşullarda, sistem patojenlerinin ortadan kaldırılmasına yardım eder, ancak skloderma gibi kronik inflamatuvar koşullar altında süperoksit radikalinin fazla birikimi tarafından karaciğer fibrozisi o nörodejenerasyonu indüklemek için geçirilir (Nazıroğlu, 2007a). Yüksek glikoz yayılmasında monosit süperoksit radikali NADPH-oksidaz tarafından serbest birakilırken, miyokondriyal solunum zinciri ve $\alpha$-tocopherol'ün protein kinaz C (PKC)-a nın inhibisyonu üzerinden süperoksit salınımını önleyen antioksidanlar tarafindan serbest bırakılmazlar. Plazma membranındaki bir fonksiyonel NADPH-oksidaz kompleksi fosforilasyon ve birkaç sitozolik alt birimlerini (p40phox, p47phox, p67phox ve Rac1/2) takip eden translokasyona bağlanır (Chanock ve ark., 2000). Mikroglia hücrelerde antioksidanlar fosfataz üzerinden PKC'yi inaktive eder - o yola aracilik eden (PP1 ve PP2A) ve bunun bir sonucu olan fosforilasyonu bloklamas1 - plazma membranında p47phox' un translokasyonunu bağlar. Sonuç olarak, mikroglial NADPH-oksidaz sistemi tarafindan süperoksit radikal üretimi önemli ölçüde engellenir. Bu durum nörodejeneratif hastalıkların bir çeşidinde $\alpha$-tocopherol gibi antioksidanların yararlı etkileri için kısmi bir açılama sunar (Nazıroğlu, 2007b).

Bakteriyi uzaklaştıran mikroglia ve hücresel atıklar, diğer aktif makrofajlara benzer şekilde, araşidonik asit türevlerini ve $\mathrm{H}_{2} \mathrm{O}_{2}$ içeren inflamatuvar yığının mediyatörlerini üretir. Bu mikroglia hücreleri MSS' de immün savunması ve doku onarımı için önemli bir faktördür. Kraft ve ark. (2004) hücre kültüründe üretilmiş serebellar granül nöronlarında TRPM2'yi saptayamamalarına rağmen, mikroglia hücrelerinde yeni kalsiyum giriş yolunun $\mathrm{H}_{2} \mathrm{O}_{2}$ ve ADPR'yi birleştirdiğini ve bu yolun TRPM2 ile ilgili olduğunu açıkladılar. Son çalışmalarda, Ohana ve ark. (2009) kantitatif gerçek zamanlı RT-PCR yardımıyla ratlardaki $\mathrm{Ca}^{+2}$ ' a geçirgen kabul edilen TRPM2 kanalları ifa- 
desini kültüre edilmiş mikroglia hücrelerinde araştırdılar. TRPM2 genleri için kültüre edilmiş rat mikroglia hücrelerinde transkript tespit ettiler.

Nörodejeneratif hastalıkların ilerlemesinde astroglia hücrelerinin rolü hala bilinmemesine rağmen, normal ve anormal nöronal çevre düzenlemesinde onların rol oynuyor olması dikkat çekicidir. $\mathrm{Ca}^{+2}$ sinyal yığını sayesinde, astroglia kontrol gen ekspresyonu, nöronal farklılaşma ve programlı hücre ölümü tüm gelişim ve dejeneratif süreçlerin ayrılmaz bir parçasını oluşturmaktadır. Oksidatif stres koşulları altında glial hücreleri ROS temizleyicisi ve zehir çıkarıcısı tarafindan koruyucu bir işlev göstermesi sebebiyle nöronlar için enerji desteği ve besleyici veya inflamatuvar faktörlerin $\mathrm{Ca}^{+2}$ 'a bağımlı salgı yoluyla dejenerasyonuna bağlı direkt nöronal direnç veya açığ 1 oluşmasını sağlar (Morale ve ark., 2006). Astroglia hücrelerindeki TRPM2 kanallarıyla ilgili olarak pek fazla rapor bulunmamaktadır. Bond ve Greenfield, (2007) oksidatif stresin önemi doğrultusunda protein sentezi baskısından ve sonraki baskılanmış aşırı protein ekspresyonundan olan uzun voltaja duyarlı $\mathrm{Ca}^{+2}$ kanalları (L-VGCC) kuşatmasının etkileri ve TRPM2 inhibisyonu geri kazanımı arttırd1ğını rapor etmişlerdir. $\mathrm{Bu}$ sonuçlar oksidatif streste $\mathrm{Ca}^{+2}$ sinyalizasyonu astroglial transkripsiyon ve translasyon yanıtlarının ayrılmaz bir parçası olduğunu göstermiştir.

\section{Hipokampal Nöronlarda TRPM2 Kanalı}

TRPM2 kanallarının farklı hücre tiplerinde mevcut olduğu bildirilmiştir. Memelilerin beyinlerinde yüksek ekspresyon için ikna edici kanıtların olmasının yanı sıra nöronal olmayan hücrelerde de bu sinyallerin çoğunun güçlü ekspresyona sahip olabileceği düşünülmüştür. $\mathrm{Bu}$ nedenle, nöronlarda fonksiyonel TRPM2'nin varlığı en iyi şekilde tartışılmalıdır. Olah ve ark., (2009) hipokampal silikalardaki CA1 inter nöronlar dahil hipokampüsün piramidal nöronlarında, fonksiyonel TRPM2 katyon kanalları son derece iyi ifade edildiğini rapor etmiştirler. Ayrıca, hipokampal nöronlardaki TRPM2 kanalını açmak için ADPR'nin tek başına yeterli olmadığını bildirdiler. Tam aktif TRPM2 kanalları için voltaja bağımlı $\mathrm{Ca}^{+2}$ kanallarında $\mathrm{Ca}^{+2}$ girişine eşlik eden akışın ve/veya NMDAR'ın gerekli olduğu sonucuna ulaştılar.

\section{DRG) Hücrelerinde TRPM2 Kanalları \\ DRG hücrelerinde iç ve dış uyaranların farlı uya-}

rılarıyla birlikte duyusal nöronların birkaç çeşitleri bulunmaktadır. Bu uyaranlar, yani nosiseptif (ağrı ve acı verici uyarıları alarak beyin merkezine iletme yeteneğine sahip), termal ve mekanik uyaranlar, sinir uçlarında duyu alıcı alanları bulunmakta ve DRG nöronlarının seçici alt gruplarında oluşan ifade de önemli fonksiyonlar oynayan katyon kanallarının yanıt profilini belirleyen aktif farklı reseptörler ve iyon kanallarıdır. TRPM8 kanalı DRG nöronlarında sadece, açıkça atanmış fonksiyona sahip TRPM kanalıdır. Hücre içi $\mathrm{Ca}^{+2}$ yükselmesiyle zararsız soğuk uyaranların, mentolün ve İsilin'in yanıtı tarafından aktive edilmektedirler (Prier ve ark., 2002). Son günlerde öncelikli olarak fare DRG hücrelerinde TRPM2 kanalları olduğu tespit edildi (Staaf ve ark., 2009). Ayrıca, embriyonik günden (12. gün) 12 haftalık oluncaya kadar farelerin DRG hücrelerinde TRPM2 kanallarına rastlanılmamasına rağmen, erişkin farelerin DRG hücresinde TRPM2 kanallarının miktarı lumbar dokuda gögüs dokusuna göre önemli ölçüde daha fazla bulundu.

\section{Sonuç}

TRPM2 nin genetik varyasyonu hastalıklara yatkınlığını gösteren bipolar bozuklukların bulunması gibi TRPM2 türevleri nörolojik hastalıklar için bir kanıt teşkil etmektedir. Benzer şekilde, reaktif oksijen türlerine yanıt olarak $\mathrm{Ca}^{+2}$ giriş yolunun önemli bir bileşeni olan TRPM2'nin belirlenmesi beyin ve nörolojik hücrelerin fizyolojisi ve patofizyolojisi üzerine yeni bir ış1k tutmaktadir.

Nörolojik ve beyin fonksiyon bozukluğunda oksidatif stresin kötüleşen rolü için önemli kanıtlar bulunmakta ve nörolojik hücrelerde TRPM2 fonksiyonlarını kontrol etmek, nörolojik ve beyin fonksiyon bozukluğunun deneysel tedavileri için gelecekte oldukça faydalı olabilir.

Nöronal hücrelerde TRPM2 kanallarının rolleri henüz kesin olarak bilinmemektedir. Bu konularda sınırlı sayıda çalışmalar mevcuttur. Özellikle DRG hücrelerinde TRPM2 kanallarının varlığ 1 ve aktivasyon mekanizmaları daha çok çalışmalarla aydınlatılmalıdır. Grubumuzun yakın zamanda yaptığı ve yayınlanmamış çalışmalarda, DRG hücrelerinde, TRPM2 kanallarının varlığ $\mathrm{Bu}$ gelişmeler olursa etiyolojisinde oksidatif stresin rol oynayabileceği öne sürülen birçok nörolojik (örneğin Alzheimer) ve psikiyatrik (örneğin bipolar I ve II) hastalığın etiyolojine katkıda bulunulacaktır. Bu konuda araştırmaların yapılmasına büyük ihtiyaç vardır.

\section{KAYNAKLAR:}

Bond, C.E., Greenfield. S.A., 2007. Multiple cascade effects of oxidative stress on astroglia. Glia. 55, 1348-1361.

Butterfield, D.A., 2003. Amyloid beta-peptide [1-42]-associated free radical-induced oxidative stres and neurodegeneration in Alzheimer's disease brain: mechanisms and consequences. Curr. Med. Chem. 10, 2651-2659.

Chanock, S.J., Roesler, J., Zhan, S., Hopkins, P., Lee, P., Barrett, D.T., Christensen, B.L., Curnutte, J.T., Görlach, A., 2000. Genomic structure of the human p47-phox (NCF1) gene. Blood Cells Mol. Dis. 26, 37-46.

Clapham, D.E., 2003. TRP channels as cellular sensors. Nature. 426, 517-524.

Clapham, D.E., 2007. Snapshot: mammalian TRP channels. Cell. 129, 220.

Fonfria, E., Marshall, I.C., Boyfield, I., Skaper, S.D., Hughes, J.P., Owen, D.E., Zhang, W., Miller, B.A., Benham, C.D., McNulty, S., 2005. Amyloid beta-peptide (1-42) and hydrogen peroxide-induced toxicity are mediated by TRPM2 in rat primary striatal cultures. J. Neurochem. 95, 715-723.

Gasser, A., Glassmeier, G., Fliegert, R., Langhorst, M.F., Meinke, S., Hein, D., Kruger, S., Weber, K., Heiner, I., Oppenheimer, N., 
Schwarz, J.R., Guse, A.H., 2006. Activation of T cell calcium influx by the second messenger ADP-ribose. J. Biol. Hem. 281, 2489-2496.

Guse, A.H., 2005. Second messenger function and the structure-activity relationship of cyclic adenosine diphosphoribose (cADPR). FEBS J. 272, 4590-4597.

Halliwell, B., 2006. Oxidative stress and neurodegeneration: where are we now? J. Neurochem. 97, 1634-1658.

Hara, Y., Wakamori, M., Ishii, M., Maeno, E., Nishida, M., Yoshida, T., Yamada, H., Shimizu, S., Mori, E., Kudoh, J., Shimizu, N., Kurose, H., Okada, Y., Imoto, K., Mori, Y., 2002. LTRPC2 Ca2+-permeable channel activated by changes in redox status confers susceptibility to cell death. Mol. Cell. 9, 163-73.

Heiner, I., Eisfeld, J., Luckhoff ,A., 2003. Role and regulation of TRP channels in neutrophil granulocytes. Cell. Calcium. 33, 53340.

Heiner, I., Eisfeld, J., Warnstedt, M., Radukina, N., Jungling, E., Luckhoff, A., 2006. Endogenous ADP-ribose enables calciumregulated cation currents through TRPM2 channels in neutrophil granulocytes. Biochem. J. 398, $225-232$.

Hill, K., Tigue, N.J., Kelsell, R.E., Benham, C.D., McNulty, S., Schaefer, M., Randall, A.D., 2006. Characterization of recombinant rat TRPM2 and a TRPM2-like conductance in cultured rat striatal neurons. Neuropharmacol. 50, 89-97.

Inamura, K., Sano, Y., Mochizuki, S., Yokoi, H., Miyake, A., Nozawa, K., Kitada, C., Matsushime, H., Furuichi, K., 2003. Response to ADP-ribose by activation of TRPM2 in the CRI-G1 insulinoma cell line. J. Membr. Biol. 191, 201-207.

Kaneko, S., Kawakami, S., Hara, Y., Wakamori, M., Itoh, E., Minami, T,, Takada, Y., Kume, T., Katsuki, H., Mori, Y., Akaike, A., 2006. A critical role of TRPM2 in neuronal cell death by hydrogen peroxide. J. Pharmacol. Sci. 101, 66-76.

Kolisek, M., Beck, A., Fleig, A., Penner, R., 2005. Cyclic ADP-ribose and hydrogen peroxide synergize with ADP-ribose in the activation of TRPM2 channels. Mol. Cell. 18, 61-69.

Kraft, R., Grimm, C., Grosse, K., Hoffmann, A., Sauerbruch, S., Kettenmann, H., Schultz, G., Harteneck, C., 2004. Hydrogen peroxide and ADP-ribose induce TRPM2-mediated calcium influx and cation currents in microglia. Am. J. Physiol. Cell. Physiol. 286, 129-137.

Kraft, R., Harteneck, C., 2005. The mammalian melastatin-related transient receptor potential cation channels: an overview. Pflugers Arch. 451, 204-211.

Kühn, F.J., Heiner, I., Luckhoff, A., 2005. TRPM2: a calcium influx pathway regulated by oxidative stress and the novel second messenger ADP-ribose. Pflugers Arch. 451, 212-219.

Kühn, F.J., Lückhoff, A., 2004. Sites of the NUDT9-H domain critical for ADP-ribose activation of the cation channel TRPM2. J. Biol. Chem. 279, 46431-46437.

Massullo, P., Sumoza-Toledo, A., Bhagat, H., Partida-Sánchez, S., 2006. TRPM channels, calcium and redox sensors during innate immune responses. Semin Cell. Dev. Biol. 17, 654-666.

Morale, M.C., Serra, P.A., L’episcopo, F., Tirolo, C., Caniglia, S., Testa, N., Gennuso, F., Giaquinta, G., Rocchitta, G., Desole, M.S., Miele, E., Marchetti, B., 2006. Estrogen, neuroinflammation and neuroprotection in Parkinson's disease: glia dictates resistance versus vulnerability to neurodegeneration. Neurosci. 138, 869-878.

Naziroglu, M., Lückhoff, A., Jungling, E., 2007. Antagonist effect of flufenamic acid on TRPM2 cation channels activated by hydrogen peroxide. Cell. Biochem Funct. 25, 383-387.

Nazıroğlu, M., Lückhoff, A., 2008a. A calcium influx pathway regulated separately by oxidative stress and ADP- ribose in TRPM2 channels: Single channel events. Neurochem Res. 33, 1256-1262.

Nazıroğlu, M., Lückhoff, A., 2008b. Effects of antioxidants on calcium influx through TRPM2 channels in transfected cells activated by hydrogen peroxide. J. Neurological. Sci. 270, 152-158.

Nazıroğlu, M., 2007a. Molecular Mechanisms of vitamin E on intracellular signaling pathways in brain. In Reactive Oxygen Species and Diseases. Ed.; Laszlo Goth, Res. Signpost Press: Kerala, India. pp 239-256.

Naziroglu, M., 2007b. New molecular mechanisms on the activation of TRPM2 channels by oxidative stress and ADP-ribose. Neurochem Res. 32, 1990-2001.

Nazıroğlu, M., 2009. Role of selenium on calcium signaling and oxidative stress- induced molecular pathways in epilepsy. Neurochem Res. 34, 2181-2191.

Nazıroğlu, M., 2010. Effects of vitamin C on oxidative stress-induced molecular pathways in epilepsy. Editor: Christina M. Jackson. In: Vitamin C: Nutrition, Side Effects and Supplements. Nova Science Publishers, Inc. ISBN: 978-1-61728-754-1.

Nilius, B., Owsianik, G., Voets, T., Peters, J.A., 2007. Transient Receptor Potential cation channels in disease. Physiol. Rev. 87, $165-217$.

Nilius, B., 2007. TRP channels in disease. Biochem Biophys. Acta. 1772, 805-812.

Ohana, L., Newell, E.W., Stanley, E.F., Schlichter, L.C., 2009. The Ca2+ release-activated $\mathrm{Ca}^{2+}$ current (ICRAC) mediates storeoperated Ca2+ entry in rat microglia. Channels. 3, 129-139.

Olah, M.E., Jackson, M.F., Li, H., Perez, Y., Sun, H.S., Kiyonaka, S., Mori, Y., Tymianski, M., MacDonald, J.F., 2009. Ca ${ }^{2+}$ dependent induction of TRPM2 currents in hippocampal neurons. J. Physiol. 587, 965-979.

Özmen, I., Nazıroğlu, M., Alicı, H.A., Sahin, F., Cengiz, M., Eren, İ., 2007. Spinal morphine administration reduces the fatty acid contents in spinal cord and brain in rabbits due to oxidative stress. Neurochem Res. 32, 19-25.

Peier, A.M., Moqrich, A., Hergarden, A.C., Reeve, A.J., Andersson, D.A., Story, G.M., Earley, T.J., Dragoni, I., McIntyre, P., Bevan, S., Patapoutian, A., 2002. A TRP channel that senses cold stimuli and menthol.Cell. 108, 705-715.

Perraud, A.L., Fleig, A., Dunn, C.A., Bagley, L.A., Launay, P., Schmitz, C., Stokes, A.J., Zhu, Q., Bessman, M.J., Penner, R., Kinet, J.P., Scharenberg, A.M., 2001. ADP-ribose gating of the calcium-permeable LTRPC2 channel revealed by Nudix motif homology. Nature. 411, 595-599.

Perraud, A.L., Schmitz, C., Scharenberg, A.M., 2003. TRPM2 $\mathrm{Ca}^{2+}$ permeable cation channels: from gene to biological function. 
Cell Calcium. 33, 519-531.

Perraud, A.L., Takanishi, C.L., Shen, B., Kang, S., Smith, M.K., Schmitz, C., Knowles, H.M., Ferraris, D., Li, W., Zhang, J., Stoddard, B.L., Scharenberg, A.M., 2005. Accumulation of free ADP-ribose from mitochondria mediates oxidative stress-induced gating of TRPM2 cation channels. J. Biol. Chem. 280, 6138-6148.

Rayman, M.P., 2009. Selenoproteins and human health: Insights from epidemiological data. Biochim Biophys Acta. 1790, 15331540.

Smith, M.A., Herson, P.S., Lee, K., Pinnock, R.D., Ashford, M.L., 2003. Hydrogen-peroxide-induced toxicity of rat striatal neurons involves activation of a nonselective cation channel. J. Physiol. 547, 417-425.

Spencer, P.S., Nunn, P.B., Hugon, J., Ludolph, A.C., Ross, S.M., Roy, D.N., Robertson, R.C., 1987. Guam amyotrophic lateral sclerosis-parkinsonism-dementia linked to a plant excitant neurotoxin. Sci. 237, 517-522.

Staaf, S., Franck, M.C., Marmigère, F., Mattsson, J.P., Ernfors, P., 2010. Dynamic expression of the TRPM subgroup of ion channels in developing mouse sensory neurons. Gene Expr Patterns 10, 65-74.

Tafti, M., Ghyselinck, N.B., 2007. Functional implication of the vitamin A signaling pathway in the brain. Arch. Neurol. 64, 17067611.

Togashi, K., Hara, Y., Tominaga, T., Higashi, T., Konishi, Y., Mori, Y., Tominaga, M., 2006. TRPM2 activation by cyclic ADP-ribose at body temperature is involved in insulin secretion. EMBO J. 25, 1804-1815.

Watanabe, H., Murakami, M., Ohba, T., Takahashi, Y., Ito, H., 2008. TRP Channel and cardiovascular disease. Pharmacol. Therap 118, 337-351.

Wehage, E., Eisfeld, J., Heiner, I., Jüngling, E., Zitt, C., Lückhoff, A., 2002. Activation of the cation channel long transient receptor potential channel 2 (LTRPC2) by hydrogen peroxide. A splice variant reveals a mode of activation independent of ADP- ribose. J. Biol. Chem. 277, 23150-23156.

Yamamoto, S., Shimizu, S., Kiyonaka, S., Takahashi, N., Wajima, T., Hara, Y., Negoro, T., Hiroi, T., Kiuchi, Y., Okada, T., Kaneko, S., Lange, I., Fleig, A., Penner, R., Nishi, M., Takeshima, H., Mori, Y., 2008. TRPM2-mediated Ca2+influx induces chemokine production in monocytes that aggravates inflammatory neutrophil infiltration. 14, 738-747. 